\title{
"Ceria"
}

Jurnal Program Studi Pendidikan Anak Usia Dini ISSN 2301-9905

Volume 10, No 1, Juli 2021

Fakultas Keguruan dan Ilmu Pendidikan- Universitas Muhammadiyah Tangerang

\section{ANALISIS MODEL PEMBELAJARAN GURU DALAM MENGENAL KONSEP BILANGAN KEPADA SISWA TAMAN KANAK KANAK}

\author{
${ }^{1}$ Iman Nurjaman, ${ }^{2}$ Puspa Resmi \\ 1,2Program studi pendidikan guru pendidikan anak usia dini fakultas \\ keguruan dan ilmu pendidikan universitas muhammadiyah kota Tamgerang \\ e-mail: ${ }^{1}$ Iman.umt@gmail.com, ${ }^{2}$ pusparesmi40@gmail.com
}

\begin{abstract}
Abstrak
Peran guru sangat menentukan dalam kegiatan pembelajaran, karena guru merupakan motivator dan penyampai ilmu pengetahuan atau informasi kepada anak didik sehingga anak mendapatkan pengalaman dan pengayaan dirinya sendiri. Penelitian ini bertujuan untuk mengetahui model pembelajaran yang diterapkan oleh guru dalam mengenalkan konsep bilangan di RA Al-Mukhlisin serta mengetahui apakah model pembelajaran terdapat permasalahan dalam mengenalkan konsep bilangan kepada siswa di RA Al Mukhlisin. Sumber dari penelitian ini adalah guru yang mengajar di RA Al- Mukhlisin Kecamatan Pinang Kota Tangerang tahun ajaran 2020/2021 yang berjumlah 3 orang. Penelitian ini menggunakan jenis penelitian kualitatif deskriptif. Sumber dari penelitian ini dilengkapi data berupa hasil wawancara. Rumusan masalah yang akan di analisis peneliti ini terbagi menjadi 2 (Dua) rumusan masalah. Berdasarkan temuan data peneliti dan pembahasan, maka peneliti menyimpulkan bahwa model pembelajaran yang diterapkan oleh guru di RA Al-mukhlisin dalam mengenalkan konsep bilangan kepada siswa adalah model klasikal. Peneliti juga menyimpulakan kembali berdasarkan temuan dilapangan, bahwa guru-guru RA Al-Mukhlisin tidak menemui kendala menerapkan model klasikal dalam mengenalkan konsep bilangan kepada siswa.
\end{abstract}

Kata kunci: model pembelajaran, konsep bilangan anak usia dini 


\section{Jurnal Program Studi Pendidikan Anak Usia Dini \\ "Ceria"}

\section{Pengantar}

Pendidikan seperti halnya di Taman Kanak Kanak merupakan pendidikan dasar yang ditujukkan untuk anak usia dini melalui konsep bermain. Secara konsep di Taman KanakKanak dikenalkan pengetahuan- pengetahuan baru yang berada disekitarnya, mulai dari anak mengenal dirinya sampai dengan mengenalkan alam semesta melalui tema-tema yang menarik dan sederhana. Konsep bilangan juga termasuk dalam tujuan pendidikan di tingkat ini, tentunya konsep bilangan ini harus diterjemahkan dalam tema yang paling sederhana dan mudah dimengerti oleh anak, yaitu salah satunya melalui pengenalan bentuk bilangan 1 sampai 10.

Pembelajaran matematika bagi anak usia dini mengikuti kebijakan pemerintah, sesuai dengan Peraturan Menteri Pendidikan dan Kebudayaan Republik Indonesia Nomor 137 tahun 2014 tentang standar pendidikan Nasional Anak Usia Dini, yaitu tingkat pencapaian perkembangan anak usia 4 -5 tahun adalah : 1) membilang banyak benda satu sampai sepuluh; 2) Mengenal konsep bilangan; 3) Mengenal lambang bilangan; dan, 4) Mengenal lambang huruf (Sumardi,\& Gustini,2017). Pernyataan tersebut menyebutkan batasan-batasan yang menjadi acuan dalam pembelajaran yang diberikan di tingkat pendidikan anak usia dini. Batasan- batasan tersebut juga dapat menjadi indikator keberhasilan pembelajaran pada anak usia dini, salah satu indikator tersebut adalah mengenal konsep bilangan.

Konsep bilangan itu bersifat abstrak, maka cenderung sukar untuk dipahami oleh anak Taman Kanak-kanak dimana pemikiran anak Taman Kanak-kanak berdasarkan pada pengalaman kongkret. Untuk dapat mengembangkan konsep bilangan pada anak Taman Kanak-kanak tidak dilakukan dalam jangka waktu pendek, yang harus dilakukan secara bertahap dalam jangka waktu yang lama, serta dibutuhkan media yang kongkret untuk membantu proses pembelajaran mengenal konsep bilangan (Fadillah \& Muhammad, 2014). Pernyataan ini menjelaskan bahwa pemikiran anak Taman Kanak-kanak dalam konsep bilangan masih berdasarkan pada pengalaman kongkret.

RA Al-Mukhlisin Kecamatan Pinang Kota Tangerang berdiri di atas lahan seluas 200 $\mathrm{m}^{2}$, dengan jumlah pendidik dan tenaga pendidik 7 orang dan jumlah siswa 30 siswa. RA Al- 
Mukhlisin masih tergolong baru, namun mempunyai visi dan misi yang mulia dalam rangka ikut serta mencerdaskan kehidupan bangsa, khususnya dalam menggali potensi anak-anak usia dini di wilayahnya baik dibidang literasi maupun numerasi. Salah satu kekurangan yang dimiliki oleh RA Al-mukhlisin adalah tenaga pengajar yang belum seluruhnya S1 (dari 7 orang hanya 3 yang sudah mencapai gelar S1 kependidikan anak usia dini). Kondisi ini dapat menjadi suatu alasan kekhawatiran bagi peneliti tentang ketercapaian standar pendidikan anak usia dini, salah satunya dalam mengenalkan konsep bilangan pada anak.

Untuk mengembangkan konsep bilangan kepada anak di Taman kanak-kanak baiknya menggunakan media yang kongkret secara bertahap dalam jangka waktu yang lama, karena akan lebih membantu proses pembelajaran dalam mengenal konsep bilangan. Pernyataan tersebut dapatlah dipahami bahwa guru memiliki peran yang sangat sentral dalam mengenalkan konsep bilangan kepada anak usia dini. Pemilihan model pembelajaran haruslah diperhitungkan secara matang agar mudah dipahami oleh anak dan mengandung unsur bermain yang menyenangkan. Tingkat penguasaan anak dalam mengenal konsep bilangan dapat menjadi tolok ukur keberhasilan guru dalam proses pembelajaran. Oleh karenanya analisis terhadap penerapan mengenal konsep bilangan kepada anak usia dini di RA Al-Mukhlisin kiranya sangat perlu dilakukan untuk membantu para guru mempertahankan atau melakukan perbaikan langkah-langkah pengenalan konsep bilangan yang selama ini telah dilakukan.

Pernyataan tersebut dapatlah dipahami bahwa guru memiliki peran yang sangat sentral dalam mengenalkan konsep bilangan kepada anak usia dini. Pemilihan model pembelajaran haruslah diperhitungkan secara matang agar mudah dipahami oleh anak dan mengandung unsur bermain yang menyenangkan. Tingkat penguasaan anak dalam mengenal konsep bilangan dapat menjadi tolok ukur keberhasilan guru dalam proses pembelajaran. Oleh karenanya analisis terhadap penerapan mengenal konsep bilangan kepada anak usia dini di RA Al-Mukhlisin kiranya sangat perlu dilakukan untuk membantu para guru mempertahankan atau melakukan perbaikan langkah-langkah pengenalan konsep bilangan yang selama ini telah dilakukan. 


\section{Jurnal Program Studi Pendidikan Anak Usia Dini \\ "Ceria"}

Adapun tujuan dari penelitian ini adalah untuk mengetahui model pembelajaran yang diterapkan oleh guru dalam mengenalkan konsep bilangan di RA Al-Mukhlisin dan apakah terdapat Permasalahan terhadap model pembelajaran yang diterapkan oleh guru dalam mengenal konsep bilangan kepada siswa RA Al-Mukhlisin. Penelitian ini diharapkan dapat menunjukkan bahwa model pembelajaran mengenal konsep bilangan di RA Al-Mukhlisin sesuai dengan tingkat perkembangan anak usia dini, sehingga penelitian ini dapat berguna bagi RA-Mukhlisin sebagai masukkan dalam meningkatkan mutu pembelajaran di masa yang akan datang.

Perkembangan kognitif biasanya mengacu kepada kemampuan yang dimiliki seorang anak apalagi pada usia dini perkembangan anak yang dicapai merupakan integrasi aspek pemahaman nilai-nilai agama dan moral, fisik, kognitif, bahasa dan sosial-emosional. Walaupun pada setiap tingkatan usia pertumbuhan dan perkembangan anak itu unik, dalam perkembangannya tetap mengikuti pola yang umum (Helmawati, 2018:83). Pendapat ini mengemukakan bahwa terdapat pola umum perkembangan pada anak usia dini, yaitu pemahaman nilai-nilai agama dan moral, fisik, kognitif, bahasa dan sosial-emosional. Berdasarkan uraian dari beberapa pendapat di atas dapat disimpulkan bahwa perkembangan kognitif adalah tahapan konstruksi proses berpikir, termasuk mengingat, pemecahan masalah, dan pengambilan keputusan, sejak kecil menuju remaja hingga dewasa.

Bagi anak usia dini Konsep bilangan merupakan dasar bagi pengembangan kemampuan matematis, sehingga anak secara mental siap mengikuti pembelajaran matematika lebih lanjut di Sekolah Dasar (Ramaini, 2012). Pendapat ini menjelaskan bahwa mengenal konsep bilangan merupakan proses kesiapan mental bagi anak untuk mempelajari matematika di tingkat lanjut. Berdasarkan pendapat para ahli di atas, disimpulkan bahwa pembelajaran pengenalan konsep bilangan pada anak usia dini menekankan pada membilang, mencocokan, dan membandingkan.

Model adalah representasi dari suatu objek, benda, atau ide-ide dalam bentuk yang disederhanakan dari kondisi atau fenomena alam. Model berisi informasi- informasi tentang suatu fenomena yang dibuat dengan tujuan untuk mempelajari fenomena sistem yang 
sebenarnya. Model dapat merupakan tiruan dari suatu benda, sistem atau kejadian yang sesungguhnya yang hanya berisi informasi- informasi yang dianggap penting untuk ditelaah. (Mahmud Achmad, 2008: 1). Kata "model" diturunkan dari bahasa latin mold (cetakan) atau pettern (pola). Menurut Mahmud Achmad (2008: 2) bahwa bentuk model secara umum ada empat, yaitu model sistem, model mental, model verbal, dan model matematika.

Belajar dan pembelajaran adalah suatu kegiatan yang tak terpissahkan dari kehidupan manusia. Dengan belajar manusia bisa mengembangkan potensipotensi yang dibawa sejak lahir. Tanpa belajar manusia tidak mungkin dapat memenuhi kebutuhannya tersebut. Kebutuhan belajar dan pembelajaran dapat terjadi dimana-mana, misalnya di lingkungan keluarga, sekolah, dan masyarakat. Kebutuhan manusia akan belajar tidak akan pernah berhenti selama manusia ada di muka bumi ini. Hal itu disebabkan karena dunia dan isinya termasuk manusia selalu berubah.

Definisi pembelajaran menurut Sadiman, dkk., (1986:2) “Belajar (learning) adalah suatu proses yang kompleks yang terjadi pada semua orang dan berlangsung seumur hidup, sejak ia masih bayi sampai ke liang lahat nanti." Belajar dapat terjadi di rumah, di sekolah, di tempat kerja, di tempat ibadah, dan di masyarakat, serta berlangsung dengan cara apa saja, dari apa, bagaimana, dan siapa saja. Salah satu tanda seseorang telah belajar adalah adanya perubahan tingkah laku dalam dirinya. Perubahan tingkah laku tersebut meliputi perubahan pengetahuan (kognitif), keterampilan (psikomotor), dan perubahan sikap atau tingkah laku (afektif).

Berdasarkan pendapat para penulis diatas, maka yang dimaksud dengan model pembelajaran mengenal konsep bilangan untuk anak usia dini adalah prosedur sistematis yang diterapkan untuk mengenalkan konsep bilangan kepada anak usia dini, kemudian dikembangkan agar efektif agar tujuan pembelajaran dapat tercapai dengan optimal.

\section{Metode}

Metode yang digunakan dalam penelitian ini adalah metode kualitatif-deskriptif. Instrumen dalam penelitian ini ialah peneliti dengan menggali data melalui naskah, 
wawancara, catatan lapangan, dokuman, dan sebagainya. Peneliti mengumpulkan informasi melalui wawancara, catatan lapangan dan dokumen untuk mendeskripsikan model pembeljaran yang telah diterapkan guru dalam mengenalkan konsep bilangan di RA AlMukhlisin Kota Tangerang.

\section{Hasil dan Pembahasan}

Dari hasil temuan dilapangan yang didapat, model pembelajaran yang diterapkan oleh guru dalam mengenal konsep bilangan kepada siswa RA Al-Mukhlisin Kota Tangerang, didasarkan atas hasil wawancara dari tanggal 14 -16 September 2020 terhadap 3 (Tiga) orang guru yang mengajar bahwa model pembelajaran yang diterapkan guru di RA Al-Mukhlisin dalam mengenal konsep bilangan pada siswa RA Al-Mukhlisin yaitu menggunakan model pembelajaran klasikal. Hal ini dinyatakan oleh guru yang mengajar di RA Al Mukhlisin, begitupun Ketiga nara sumber juga tidak mempunyai penjelasan mengenai kekurangan model pembelajaran klasikal selama mengenalkan konsep bilangan kepada siswa RA AlMukhlisin. Dari hasil diatas tidak ada permasalahan kepada siswa di RA Al Mukhlisin, namun sebaliknya terjadi pencapaian yang disignifikan dalam mengenal konsep bilangan. Berdasarkan dokumentasi yang diperoleh yaitu berupa nilai raport, dari data pencapaian yang diperoleh oleh para siswa, dalam mengenal konsep bilangan, bahwa pencapaian siswa dalam mengenal konsep bilangan mempunyai kriteria baik sampai dengan sangat baik.

Model pembelajaran yang diterapkan oleh guru dalam mengenalkan konsep bilangan kepada siswa RA Al-Mukhlisin yaitu semuanya adalah model klasikal. Menurut Hijriati (2017) model pembelajaran klasikal adalah pola pembelajaran di mana dalam waktu yang sama, kegiatan dilakukan oleh seluruh anak sama dalam satu kelas.

Model pembelajaran kalsikal menjadi pilihan utama guru-guru RA Al-Mukhlisin dalam pengamatan penulis karena keterbatasan sarana dan prasarana pembelajaran. Seperti yang dijelaskan oleh Syamsuardi dan Hajerah (2018), dalam menerapkan model pembelajan pada masing-masing lembaga dipengaruhi oleh faktor pendukung dan penghambat pada setiap lembaga dimana berdasarkan hasil penelitian diperoleh faktor yang mempengaruhi 
efektifitas penggunaan model pembelajaran adalah ketersediaan sarana dan prasarana proses pembelajaran menjadi pendukung utama sekaligus sebagai faktor penghambat .

RA Al-Mukhlisin belum mempunyai ruang kelas yang banyak, sehingga belum mampu untuk menerapkan seperti halnya model pembelajaran sentra yang beroirientasi pada penerapan system moving class yang memerlukan ruang belajar sesuai dengan jenis sentra yang akan disediakan. Kondisi demikian seperti yang dikemukakan oleh Ita (2018) yang mengemukakan bahwa model pembelajaran inovatif seperti model pembelajaran berbasis sudut, model pembelajaran berbasis area, dan model pembelajaran berbasis sentra tidak dapat digunakan dikarenakan sarana dan prasarana pembelajaran yang belum memadai untuk diterapkan model pembelajaran-model pembelajaran inovatif tersebut. Dalam kondisi keterbatasan sarana dan prasarana RA Al-Mukhlisin telah berupaya untuk memberikan manfaat dalam mencerdaskan anak bangsa, selain tentunya mereka yang mengetahui kondisi dari para siswanya yang mungkin lebih cenderung auditif (mendengarkan) dalam belajar. Maka dari itu, para guru mempunyai cara tersendiri dalam proses pembelajarannya yaitu dengan cara menggunakan gerak tubuh, menggunakan benda-benda, dan nada-nada seperti bernyanyi ataupun lainnya dalam mengenalkan konsep bilangan, dan lebih mudah dipahami oleh siswa di RA Al-Mukhlisin tersebut.

Cara seperti ini tentu menuntut kesabaran dan dedikasi yang luar biasa dari para guru. Di titik inilah penulis berpendapat bahwa kompetensi para guru di RA Al-Mukhlisin tidaklah perlu diragukan, karena dengan menerapkan pengulangan secara terus menerus tentu juga diperlukan kreativitas dan kompetensi pedagogik yang baik agar siswa tidak merasa bosan, terintimidasi, mampu mengembangkan imajinasinya dan lain-lain.

\section{Kesimpulan}

Berdasarkan temuan data dan pembahasan, maka dapat disimpulkan model pembelajaran yang diterapkan oleh guru di RA Al-mukhlisin dalam mengenalkan konsep bilangan kepada siswa adalah model klasikal, Guru-Guru RA Al-Mukhlisin 
"Ceria"

tidak menemui kendala menerapkan model klasikal dalam mengenalkan konsep bilangan kepada siswa.

\section{Daftar Acuan}

Sumardi Taopik Rahman, I. syifa gustini. (2017). Peningkatan Kemampuan Anak Usia Dini Mengenal Konsep Bilangan melalui Media Flashcard. Jurnal Paud Agapedia, 1(1), 118-128.

Fadillah, A., \& Muhammad, R. (2014). Upaya meningkatkan kemampuan mengenal konsep bilangan melalui media gambar pada anak di kelompok bermain tunas harapan. 1-6.

Ramaini. (2012). PENINGKATAN KEMAMPUAN MENGENAL KONSEP BILANGAN MELALUI PERMAINAN TABUNG PINTAR di TK NEGERI PEMBINA LUBUK BASUNG. Ejournal, 53(9), 4.

Hijriati. (2017). PENGEMBANGAN MODEL PEMBELAJARAN PENDIDIKAN ANAK USIA DINI Hijriati. III, 74-92.

Helmawati. (2018). MENGENAL DAN MEMAHAMI PAUD (P. Latifah, ed.).

Bandung. 